Aletria, Belo Horizonte, v. 28, n. 1, p. 273-276, 2018

\title{
SCHÜLER, Donaldo. Joyce era louco?. São Paulo: Ateliê Editorial, 2017. 238 p.
}

Leide Daiane de Almeida Oliveira

Universidade Federal de Santa Catarina, Florianópolis, Santa Catarina / Brasil daiane.deao@gmail.com

A questão levantada por Jaques Lacan em seu seminário de número 23, dedicado à obra de James Joyce, é escolhida por Donaldo Schüler como título do seu mais novo livro: Joyce era louco?. O leitor e a leitora são convidados a adentrar uma obra em que se entrelaçam questões psicanalíticas, políticas e literárias. A quantidade impressionante de referências literárias, filosóficas, mitológicas etc., na construção de sua releitura das duas últimas obras do escritor irlandês, James Joyce (1822-1941), demonstra uma espantosa erudição. Sua capacidade de articulação dos temas apresentados oferece ao leitor e à leitora uma rica imersão, tanto na obra joyceana quanto nas investigações de Lacan sobre a fascinante escrita de Joyce.

O livro é dividido em cinco capítulos. O primeiro, intitulado "Loucuras", traz uma ampla contextualização sobre a noção de loucura e sua oscilação conceitual ao longo dos tempos. Schüler parte da mitologia grega, discutindo sobre as mênades e musas, passa pelo conto de Machado de Assis, O alienista, por O elogio da loucura, de Erasmo de Rotterdam, por "Orlando furioso", poema épico de Ariosto, e também por Gargântua, romance de Rabelais, apenas para citar algumas de suas referências para discutir o tema da loucura. Ainda nesse capítulo, o autor entra mais especificamente na questão da loucura sob a perspectiva psicanalítica, para então partir para a discussão a respeito do interesse de Lacan na obra de Joyce. 
O questionamento a respeito da sanidade mental de Joyce provavelmente tem sua origem na constatação da impressionante inventividade de sua escrita. Como escreve Schüler: "James Joyce desperta em si o criador. As invenções delirantes de Joyce libertam, projetam voos inesperados". ${ }^{1}$ Um desses voos se dá em Ulysses e é justamente a essa obra que Schüler dedica o segundo capítulo de seu livro. Nesse capítulo, intitulado "Ulysses", Schüler passeia pelos 18 capítulos da penúltima obra de Joyce, oferecendo uma releitura repleta de outras referências, principalmente relacionando Ulysses à Odisseia de Homero, obra na qual Joyce se inspirou para escrever sua epopeia moderna. Schüler aprofunda ainda a análise dos personagens principais da obra, trazendo muitas contribuições para uma compreensão mais apurada de sua complexidade e riqueza.

O segundo capítulo, o mais extenso do livro, é seguido por um capítulo dedicado a alguns aspectos do Finnegans Wake, cuja única tradução integral foi realizada também por Donaldo Schüler. No terceiro capítulo, intitulado "Riverrun", palavra criada por Joyce para iniciar seu último romance, Schüler retoma a questão que dá título a esse livro. A resposta de Lacan à sua própria pergunta, feita durante seu seminário dedicado à obra de Joyce, na Sorbonne, é que: "a mania reflete-se na última obra de Joyce, Finnegans Wake". ${ }^{2}$ Entre incursões psicanalíticas e literárias, Schüler leva o leitor e a leitora a desejar visitar a "história do mundo", que na obra de Joyce está escrita em camadas geológicas, as runas do mundo, como ele afirma. Dentre as diversas facetas da obra, o aspecto político salientado por Schüler salta aos olhos, principalmente pelo momento de crise política que o mundo tem vivenciado nos últimos tempos.

Schüler comenta que: "Toda escrita rebelde desestabiliza sistemas" e, ainda, que "ninguém se aventurou às ousadias de Joyce". ${ }^{3}$ As ousadias de Joyce foram capazes de desestabilizar a língua inglesa, uma espécie de vingança pelo longo e doloroso processo de colonização que sua terra natal, a Irlanda, foi impelida a passar. Finnegans Wake, entre outras coisas, uma obra política de Joyce, revela-se em pequenas porções. "O sujeito não esplende na imagem especular nem na assinatura. A busca

\footnotetext{
${ }^{1}$ SCHÜLER. Joyce era louco?, p. 31.

${ }^{2}$ SCHÜLER. Joyce era louco?, p. 129.

${ }^{3}$ SCHÜLER. Joyce era louco?, p. 147.
} 
analítica progride em leitura cuidadosa rumo ao escondido. Tampouco Finnegans Wake se rende a olhares apressados". ${ }^{4}$

No quarto capítulo, intitulado "Lituraterra", a articulação filosófica presente na discussão traz à tona questões políticas importantes, bem como uma crítica ferrenha ao Estado. "A máquina estatal insegura, ainda que rotulada de democrática, privilegia uns, inferniza a vida de outros, conduz multidões como rebanhos submissos, objetualiza (entifica) a si mesma e a todos, o voto oferecido e vigiado produz a ilusão da liberdade". ${ }^{5}$ As várias questões políticas presentes no texto, frequentemente postas com o intermédio da filosofia, da literatura, do cinema e da mitologia, levam o autor a concluir que: "A letra guarda o último rastro da visibilidade, confronta a sombra, a velocidade que ainda não se fez luz - literatura". ${ }^{6}$

No quinto e último capítulo da obra, "Joyce, o Enigma", a questão da suposta loucura joyceana é novamente visitada. Nesse capítulo, personalidades e personagens se revezam para dar nome às seções. Passamos por Moisés, Miguel Ângelo, Fernando Pessoa, Lear e Quixote, para então encontrarmos Arthur Bispo do Rosário, "épico das artes visuais" que é comparado a Joyce, "iluminado e ilimitado como o romancista irlandês". ${ }^{7}$ Das muitas vezes que a pergunta que dá título ao livro foi lançada, diferentes "respostas" foram ensaiadas. "Joyce era louco? Ao desarticular o mundo que o assombra, um pesadelo, Joyce age como criador, cria-se a si mesmo, contribui para que leitores ativos se evadam da rigidez petrificante. Em lugar de impor falsidades, Joyce denuncia mentiras". ${ }^{8}$ A fascinante criação literária de Joyce, que com frequência foi julgada como disparate, sobretudo com o início da publicação serializada de Work in Progress, na revista Transition, de Eugene Jolas, não foi intimidada com a avalanche de críticas negativas, pelo contrário, como bem coloca Schüler: "Joyce não cessa de escrever, abre buracos no simbólico, desarticula ideias e palavras, mina monumentos, constrói, encadeia borromeanamente o infinito. [...] A escrita o instala no mundo, revira o mundo, restaura o mundo". ${ }^{9} \mathrm{Se}$

\footnotetext{
${ }^{4}$ SCHÜLER. Joyce era louco?, p. 176.

${ }^{5}$ SCHÜLER. Joyce era louco?, p. 195.

${ }^{6}$ SCHÜLER. Joyce era louco?, p. 214.

${ }^{7}$ SCHÜLER. Joyce era louco?, p. 233.

${ }^{8}$ SCHÜLER. Joyce era louco?, p. 119.

${ }^{9}$ SCHÜLER. Joyce era louco?, p. 225.
} 
Joyce foi louco, teria sido, como Schüler argumenta, como os surrealistas, construtores de realidades outras, mas sem jamais se subordinarem a elas.

Joyce era louco? A pergunta que permeia esse livro, aparecendo tanto em seu título quanto inúmeras vezes ao logo dos capítulos, não traz consigo uma resposta objetiva; ao invés disso, convida o leitor e a leitora a refletir sobre muitas outras questões que são levantadas ao longo da instigante escrita de Donaldo Schüler. A literatura é apresentada como uma potente arma política. Esse é um livro necessário e corajoso.

Recebido em: 15 de dezembro de 2017. Aprovado em: 15 de fevereiro de 2018. 